\title{
Simultaneous removal of COD and Ammoniacal Nitrogen from dye intermediate manufacturing Industrial Wastewater using Fenton oxidation method
}

\author{
Nibedita Pani ${ }^{1} \cdot$ Vishnu Tejani $^{2} \cdot$ T. S. Anantha-Singh ${ }^{2}$ (D) $\cdot$ Anurag Kandya $^{2}$
}

Received: 15 April 2019 / Accepted: 21 January 2020 / Published online: 29 January 2020

(c) The Author(s) 2020

\begin{abstract}
The untreated wastewater from the dye industry having high ammoniacal nitrogen and chemical oxygen demand (COD) significantly pollutes the receiving water, such as a river, having major ill implications on the aquatic environment. The present study is undertaken to address this problem. It investigates the effectiveness of Fenton reagent in simultaneous treatment (removal) of ammoniacal nitrogen and COD present in the wastewater by varying the parameters like $\mathrm{pH}$, concentration of $\mathrm{Fe}^{2+}$ and $\mathrm{H}_{2} \mathrm{O}_{2}$ and their molar ratio. The reaction time for all the experiments was kept $60 \mathrm{~min}$. The experimental analysis in terms of calculating the residual \% of ammoniacal nitrogen and COD revealed that the maximum reduction occurred at $\mathrm{pH}$ 3. At this $\mathrm{pH}$, further set of experiments were performed by varying the molar doses of $\mathrm{Fe}^{2+} / \mathrm{H}_{2} \mathrm{O}_{2}$ as 1:1, 3:3 and 5:5, and the results reveal that the maximum reduction in both ammoniacal nitrogen and COD happens at molar dose of 3:3. To understand the effect of the concentration of $\mathrm{Fe}^{2+}$ and $\mathrm{H}_{2} \mathrm{O}_{2}$ on the respective removal efficiency, set of experiments were performed by taking the molar ratio of $\mathrm{Fe}^{2+} / \mathrm{H}_{2} \mathrm{O}_{2}$ as 2:1, 3:1, 5:1, 1:2, 1:3 and 1:5. The experimental analysis reveals that the maximum reduction happened at molar ratio 1:3. Fenton process can mineralize the pollutants up to $75.8 \%$ and $78.6 \%$ for ammoniacal nitrogen and COD removal. The findings of the study would be of great use for planning and optimizing the wastewater treatment facility for the dye intermediate industry.
\end{abstract}

Keywords Ammoniacal nitrogen $\cdot$ COD $\cdot$ Dye intermediate wastewater $\cdot$ Fenton process $\cdot$ Molar dosage $\cdot \mathrm{pH}$

\section{Introduction}

In India, the production of dyestuff and pigments is more than 80,000 tonnes per annum (Nidheesh et al. 2018). Textile industries are the main users of the dyestuff. Gujarat is textile hub of India with more than 1500 textile industries (Bhatia et al. 2018; Paździor et al. 2018). These industries contribute more than $40 \%$ of the Indian dyestuff production and more than $60 \%$ of Indian exports of dyestuff. The typical wastewater generation from these industries is between

T. S. Anantha-Singh

anantha.singh@sot.pdpu.ac.in; singh87nitt@gmail.com

1 Department of Science, School of Technology, Pandit Deendayal Petroleum University, Gandhinagar 382007, India

2 Department of Civil Engineering, School of Technology, Pandit Deendayal Petroleum University, Gandhinagar 382007, India
125 and $150 \mathrm{~L}$ per kg of finished dye products (Rathi 2003; Markandeya et al. 2018).

Industrial wastewater is generally characterized by extensive contamination with organic compounds, halogenated aliphatic and aromatic compounds, agrochemicals, high concentrations of heavy metals, sulphur and nitrogen-containing compounds, high COD, TDS and TSS (Bolong et al. 2009; Dükkanci et al. 2014; Gonzalez-Merchan et al. 2016). The wastewaters from the dye intermediate industry are highly acidic and contain nitrogenous pollutants (various compounds of nitrate, nitrite and ammoniacal nitrogen), carbonaceous pollutants and other toxic compounds which are hazardous to the human health and to the aquatic environment (Bhatia et al. 2018; Markandeya et al. 2018; Kaur et al. 2019). Nitrogenous and carbonaceous compounds present in the wastewater not only deplete the DO of the receiving water but also cause eutrophication (Camargo and Alonso 2006; Huang et al. 2014). Eutrophication favours the growth of toxin-producing cyanobacteria. Exposure to such toxins causes high health risks like liver damage, skin irritation 
and liver cancer (Akpor and Muchie 2011). Ammoniacal nitrogen when converted to nitrate nitrogen causes high nitrogenous oxygen demand (NOD) which leads to methemoglobinemia. Ammoniacal nitrogen also affects the chlorine disinfection efficiency (Oturan and Aaron 2014; Karri et al. 2018).

Many technologies are available for the treatment of some primary pollutants and their derivatives present in the wastewater from the dye industry; however, the issue of removal of nitrogen from wastewater is now a matter of immediate concern. Degradation/removal of ammoniacal nitrogen includes physical, chemical and biological methods. Various chemical methods such as breakpoint chlorination, precipitation and ion exchange; physical methods like ammonia stripping and membrane separation; and biological methods such as nitrification, denitrification and advanced oxidation processes such as ozonation, sonolysis, wet air oxidation and UV-based oxidation processes are used for the degradation and removal of ammoniacal nitrogen from textile industrial wastewater (Yuan et al. 2016; Nancharaiah et al. 2016; Katheresan et al. 2018). The disadvantages include high retention time, low removal rate, high reaction time, high sludge formation, etc. Chemical process includes ion exchange and breakpoint chlorination for treatment of low-strength ammoniacal nitrogen (Wang et al. 2006); however, ion exchange process is more expensive than the conventional processes (Lotito et al. 2012; Buthiyappan and Abdul Raman 2019). The physical processes for ammoniacal nitrogen removal, i.e. air stripping, is applicable to concentration levels of $10-100(\mathrm{mg} / \mathrm{l})$. Higher ammonia content requires alternative removal technique (Karri et al. 2018). Biological process in particular nitrification and denitrification methods is poor in removing ammoniacal nitrogen due to longer treatment time and low rate of removal efficiency (Sabumon 2007; Ge et al. 2014).

The task of providing proper treatment facility for the removal of ammoniacal nitrogen $\left(\mathrm{NH}_{4}-\mathrm{N}\right)$ from the wastewaters from the dye intermediate industry is not only difficult but also expensive too; hence, there is a strong need of a new or modified technology which overcomes the limitations of the conventional methods (Hasanoglu et al. 2010; Karri et al. 2018). Advanced oxidation processes (AOPs) drew the attention of researchers for its advantages as it works in ambient temperature and pressure, it has less reaction time and is more economical and feasible than conventional methods (Guedes et al. 2003; Khatri et al. 2018; Zhang and Zhou 2019). Fenton oxidative process is used for the oxidation of organic pollutants by using nascent hydroxyl ion resulted from the reaction of hydrogen peroxide by ferrous ion (Quan et al. 2010; Gonzalez-Merchan et al. 2016; Nidheesh 2015). The various advantages of Fenton reagent over other methods are given in Table 1.

Among the common oxidants, the hydroxyl radicals, which are second only to fluorine, can react rapidly and non-selectively with nearly all-organic pollutants (da Silva Brito et al. 2019).

Equations (1) and (2) symbolize main reactions of the system.

$\mathrm{H}_{2} \mathrm{O}_{2} \rightarrow \mathrm{H}_{2} \mathrm{O}+1 / 2 \mathrm{O}_{2}$

$\mathrm{H}_{2} \mathrm{O}_{2}+\mathrm{Fe}^{2+} \rightarrow \mathrm{Fe}^{3+}+\mathrm{OH}^{-}+\mathrm{OH}^{\cdot}$

The reaction of organic species with $\mathrm{OH}^{-}$radical is represented in Eq. (3).

$\mathrm{RH}+\mathrm{OH}^{*} \rightarrow \mathrm{R}^{*}+\mathrm{OH}$

The $\mathrm{OH}$ radical reacts with $\mathrm{NH}_{4}{ }^{+}-\mathrm{N} / \mathrm{NH}_{3}-\mathrm{N}$ to give the following products and is represented in Eq. (4).

$\mathrm{NH}_{4}^{+}-\mathrm{N}+\mathrm{OH} \rightarrow \mathrm{NH}_{2} \mathrm{OH} \rightarrow \mathrm{NOH} \rightarrow \mathrm{NO} \rightarrow \mathrm{HNO}_{2} \leftrightarrow \mathrm{HNO}_{3}$

In the present study, investigations were done on the application of Fenton oxidation process for simultaneous degradation of COD and ammoniacal nitrogen from dye intermediate industrial wastewater. The various operating parameters like $\mathrm{pH}$, concentration of $\mathrm{Fe}^{2+}$ and concentration of $\mathrm{H}_{2} \mathrm{O}_{2}$ were taken into consideration, and their effects on

Table 1 Advantages of Fenton reagent

\begin{tabular}{ll}
\hline Advantages & References \\
\hline $\begin{array}{l}\text { They can oxidize organic contaminants and metals, contributing to their degrada- } \\
\text { tion and transformation }\end{array}$ & $\begin{array}{l}\text { Barbusiński and Majewski (2003), Moussavi and Matavos- } \\
\text { Aramyan (2016) and Shao et al. (2016) } \\
\text { Eren and Acar (2006) and Nidheesh and Gandhimathi (2012) }\end{array}$ \\
$\begin{array}{l}\text { The main advantage is the complete destruction of contaminants to harmless } \\
\text { compounds, e.g. carbon dioxide, water and inorganic salts }\end{array}$ & $\begin{array}{l}\text { Tony et al. (2016) } \\
\text { It allows high mineralization level at room temperature and pressure conditions }\end{array}$ \\
$\begin{array}{l}\text { No energy input is necessary to activate hydrogen peroxide } \\
\begin{array}{l}\text { It is a cost-effective source of hydroxyl radicals, using easy-to-handle reagents } \\
\text { and commonly requires a relatively short reaction time }\end{array}\end{array}$ \\
$\begin{array}{l}\text { These are relatively reasonably priced, and the process is easy to operate and } \\
\text { maintain }\end{array}$ & $\begin{array}{l}\text { Nidheesh and Gandhimathi (2012) and Singa et al. (2018) } \\
\end{array}$
\end{tabular}


the removal efficiencies of COD and ammoniacal nitrogen were examined.

\section{Materials and methodology}

\section{Materials used}

The dye manufacturing industrial raw wastewater samples were collected in a $20 \mathrm{~L}$ can from GIDC, Ankleshwar, Gujarat, and characterization of wastewater was done as per standard methods of American Public Health Association and is given in Table 2.

$\mathrm{H}_{2} \mathrm{O}_{2}$ used for the study was of Merck brand of $30 \%$ W/W purity, $\mathrm{FeSO}_{4}$ was of Finar Analytical grade with 99\% purity, and $\mathrm{NaOH}$ was of Finar Brand of Analytical grade with $96 \%$ purity. Boric acid, borate buffer, methyl red and methylene blue of Analytical grade and Merck brand were used for the analysis of ammoniacal nitrogen. For the analysis of COD, potassium dichromate (Merck brand) of Analytical grade, concentrated sulphuric acid of $98 \%$ purity (Finar brand), mercury sulphate, silver sulphate and ferrous ammonium sulphate (Merck brand) of Analytical grade were used.

\section{Experimental reactor and procedure}

A measured quantity of the sample was taken in a batch reactor with a working volume of $1000 \mathrm{~mL}$. In order to see the impact of $\mathrm{pH}$ on the removal efficiency for COD and ammoniacal nitrogen and subsequently workout the optimum $\mathrm{pH}$ value, the $\mathrm{pH}$ of the solution was varied between 1.5 and 3.5 with $1 \mathrm{~mL} \mathrm{H}_{2} \mathrm{O}_{2}$ and $0.4928 \mathrm{~g}$ of $\mathrm{Fe}^{2+}$ (molar ratio as 1:1). Another set of experiments were done by taking different molar doses of $\mathrm{Fe}^{2+} / \mathrm{H}_{2} \mathrm{O}_{2}$ which were 1:1, 3:3, 5:5, 1:2, 1:3, 1:5, 2:1, 3:1 and 5:1. All the experiments were done at room temperature. The COD analysis was done using COD digester with closed reflux apparatus, and ammoniacal nitrogen analysis was carried out by conventional distillation apparatus for ammonia.

Table 2 Characteristics of raw dye intermediate wastewater

\begin{tabular}{ll}
\hline Parameters & $\begin{array}{l}\text { Concentration } \\
\text { in mg/L (except } \\
\text { pH) }\end{array}$ \\
\hline pH & 1.53 \\
TSS & 250 \\
TDS & 32,600 \\
TS & 32,850 \\
COD & 5632 \\
Ammoniacal nitrogen & 1372 \\
\hline
\end{tabular}

\section{Results and discussion}

\section{Effect of pH on COD and ammoniacal nitrogen removal}

The Fenton oxidation process is influenced by the initial $\mathrm{pH}$ of the sample. The production of $\mathrm{OH}^{\prime}$ radical and concentration of $\mathrm{Fe}$ in $\mathrm{Fe}^{2+}$ or $\mathrm{Fe}^{3+}$ form are controlled by $\mathrm{pH}$; hence, it is an important parameter in Fenton process (Kang and Hwang 2000; Meng et al. 2019). The oxidation potential of $\mathrm{OH}$ radicals decreases with increasing $\mathrm{pH}$. The Fenton oxidation is effective in acidic medium and slow in alkaline medium and works pre-eminent at $\mathrm{pH} 2-4$.

Higher $\mathrm{pH}$ conditions $(>4.5)$ retard the formation of $\mathrm{OH}$ radicals due to decomposition of $\mathrm{H}_{2} \mathrm{O}_{2}$ into $\mathrm{O}_{2}$ gas and lose its oxidation ability. On the other hand, extreme acidic conditions are also not conducive for the generation of $\mathrm{OH}$ radical. Under highly acidic conditions, solvation of $\mathrm{H}_{2} \mathrm{O}_{2}$ occurs and it becomes more stable, which reduces its reactivity with ferrous ions to generate $\mathrm{OH}^{2}$ radicals (Deng and Zhao 2015). Oxonium $\left(\mathrm{H}_{3} \mathrm{O}_{2}\right)+$ ion is formed at higher concentration of $\mathrm{H}^{+}$which enhances the stability of $\mathrm{H}_{2} \mathrm{O}_{2}$ and prevents it from reacting with ferrous ion. The efficiency of the Fenton process to degrade ammoniacal nitrogen is reduced at both high and low pH (Wang et al. 2016). Moreover, the degradation was also slower, which was due to the formation of iron species capable of inhibiting the reaction between $\mathrm{Fe}^{2+}$ and $\mathrm{H}_{2} \mathrm{O}_{2}$. Therefore, to improve the overall degradation efficiency for efficient generation of $\mathrm{OH}$ radical, $\mathrm{pH}$ value needs to be optimized (Barros et al. 2006; Dükkanci et al. 2014).

In the present study, the effect of $\mathrm{pH}$ on removal of $\mathrm{COD}$ and ammoniacal nitrogen was investigated. The $\mathrm{pH}$ was varied between 1.5 and 3.5, and another experiment was performed without disturbing the initial $\mathrm{pH}$ of the sample which was 1.53 . Concentration-pH profile on degradation of COD and ammoniacal nitrogen is shown in Fig. 1. The fraction remaining $\left(C / C_{0}\right)$ at $\mathrm{pH} 1.53,2.5$, 3.0 and 3.5 was found as $0.352,0.284,0.227$ and 0.272 for COD removal and $0.363,0.342,0.251$ and 0.279 for ammoniacal nitrogen removal, respectively. It can be seen from Fig. 1 that COD and ammoniacal nitrogen removal increased up to $\mathrm{pH} 3$ and dropped at $\mathrm{pH} 3.5$. The $C / C_{0}$ values for $\mathrm{COD}$ and ammoniacal nitrogen at original $\mathrm{pH}$ of 1.53 were found as 0.352 and 0.363 , respectively.

The maximum COD and ammoniacal nitrogen removal (lowest value of $C / C_{0}$ ) was achieved at $\mathrm{pH} 3$, and it was found to be decreasing by increasing the $\mathrm{pH}$ to 3.5 . At lower $\mathrm{pH}$, when the initial $\mathrm{pH}$ was lower than the optimum $\mathrm{pH}$ value ( $\mathrm{pH} 3$ ), complex species such as (Fe(II) $\left.\left(\mathrm{H}_{2} \mathrm{O}\right)_{6}\right)^{2+}$ and $\left(\mathrm{Fe}(\mathrm{II})(\mathrm{OH})\left(\mathrm{H}_{2} \mathrm{O}\right)_{5}\right)^{+}$are formed by $\mathrm{Fe}^{2+}$, which in turn reacted very slowly with $\mathrm{H}_{2} \mathrm{O}_{2}$ and produced less $\mathrm{OH}^{-}$radicals. $\mathrm{OH}^{-}$radical was scavenged by $\mathrm{H}^{+}$at low 


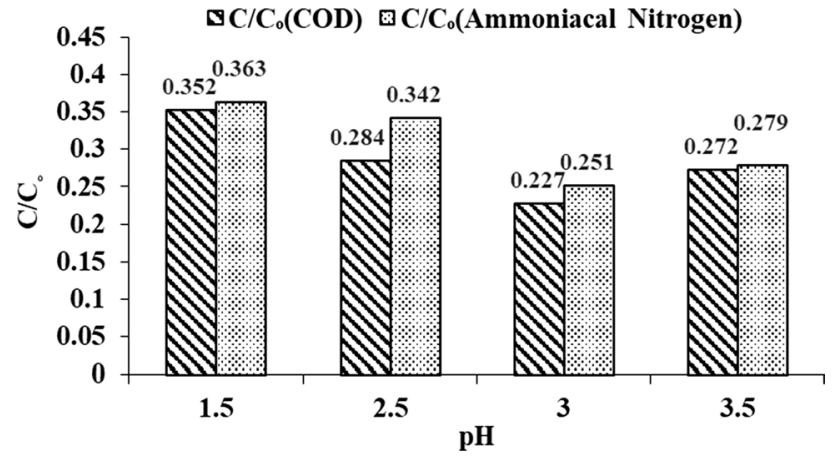

Fig. 1 Profile of fraction remaining set against $\mathrm{pH}$ on degradation of $\mathrm{COD}$ and ammoniacal nitrogen by Fenton process using molar ratio of $\mathrm{Fe}^{2+} / \mathrm{H}_{2} \mathrm{O}_{2}$ as $1: 1$

$\mathrm{pH}$ and resulted in inhibition reaction of $\mathrm{Fe}^{2+}$ and $\mathrm{H}_{2} \mathrm{O}_{2}$ as shown in Eq. (5) (Gogate and Pandit 2004; Nidheesh and Gandhimathi 2014).

$\mathrm{OH}^{-}+\mathrm{H}^{+}+\mathrm{e}^{-} \rightarrow \mathrm{H}_{2} \mathrm{O}$

The variation of the COD and ammoniacal nitrogen removal with $\mathrm{pH}$ observed in the present study converges with the previous studies (Kang and Hwang 2000; Wang et al. 2016).

\section{Effect of $\mathrm{Fe}^{2+}$ dosage}

$\mathrm{Fe}^{2+}$ dosage is an important factor to be considered for running Fenton reaction as it acts as a catalyst to decompose $\mathrm{H}_{2} \mathrm{O}_{2}$ to generate $\mathrm{OH}$ radicals. Excessive $\mathrm{Fe}^{2+}$ results in self-consumption of free radicals and hinders the oxidation reaction and produces large amount of sludge (Papić et al. 2009). At a $\mathrm{Fe}^{2+}$ concentration higher than the optimum, the rate of $\mathrm{OH}^{-}$ radicals originated from the decomposition of $\mathrm{H}_{2} \mathrm{O}_{2}$ is so high that most of the $\mathrm{OH}$ radicals are consumed by the side reactions before they are utilized for the removal of the pollutant (Jiang et al. 2010; Chen et al. 2017).

To understand the proper dosages required to enhance removal efficiency, experiments were performed by taking molar ratio of $\mathrm{Fe}^{2+} / \mathrm{H}_{2} \mathrm{O}_{2}$ as 2:1, 3:1 and 5:1. The fraction remaining obtained for $\mathrm{COD}$ and ammoniacal nitrogen was $0.320,0.298,0.372$ and $0.377,0.331$ and 0.411 , respectively. As shown in Fig. 2, the highest removal efficiency of COD and ammoniacal nitrogen was found at $\mathrm{Fe}^{2+} / \mathrm{H}_{2} \mathrm{O}_{2}$ molar ratio 3:1 at $\mathrm{pH} 3$ with reaction time of $60 \mathrm{~min}$. Addition of excess Fe(II) resulted in brown-coloured sludge formation due to formation of Fe(III) radicals.

\section{Effect of $\mathrm{H}_{2} \mathrm{O}_{2}$ dosage}

$\mathrm{H}_{2} \mathrm{O}_{2}$ is the source of $\mathrm{OH}$ radicals, and therefore, its concentration significantly affects the degradation of ammoniacal

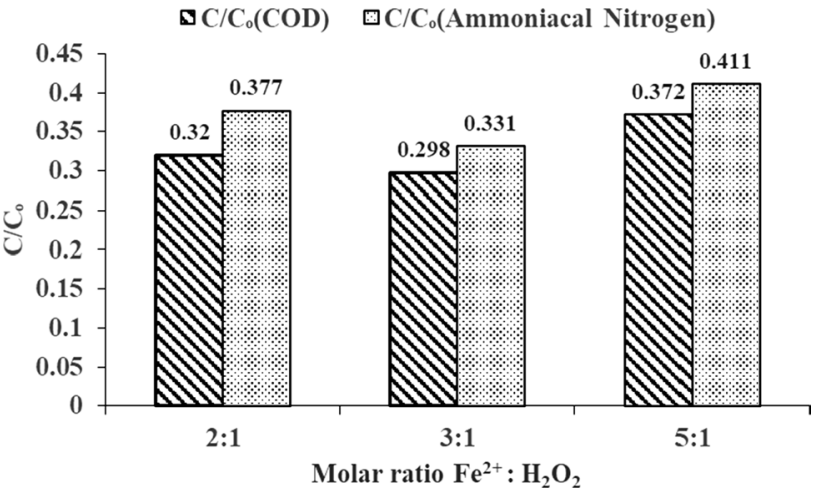

Fig. 2 Profile of fraction remaining set against molar ratio on degradation of $\mathrm{COD}$ and ammoniacal nitrogen by Fenton process at $\mathrm{pH}$ 3.0 and keeping $\mathrm{H}_{2} \mathrm{O}_{2}$ molar concentration constant and varying $\mathrm{Fe}^{2+}$ dosage (sample volume $1000 \mathrm{~mL}$ )

nitrogen and COD. The reaction rate tends to increase with increasing $\mathrm{H}_{2} \mathrm{O}_{2}$ concentration. As there are series of intermediate reactions which takes place in the process, sufficient $\mathrm{H}_{2} \mathrm{O}_{2}$ must be added in order to push the reaction beyond that point (Güneş et al. 2018).

In this study, the effect of the concentration of $\mathrm{H}_{2} \mathrm{O}_{2}$ was investigated on the removal of $\mathrm{COD}$ and ammoniacal nitrogen. Experiments were performed at $\mathrm{Fe}^{2+} / \mathrm{H}_{2} \mathrm{O}_{2}$ molar ratio $1: 2,1: 3$ and $1: 5$ at $\mathrm{pH} 3$ with the reaction time of $60 \mathrm{~min}$. Figure 3 shows the fraction remaining $\left(C / C_{0}\right)$ for COD. From the figure, it can be seen that the maximum reduction in the $\mathrm{COD}$ was at molar ratio 1:3. Moreover, it can be seen that the higher $\mathrm{H}_{2} \mathrm{O}_{2}$ concentration had a scavenging effect on the $\mathrm{OH}$ radicals resulting in the dip in COD removal. The same pattern was achieved for ammoniacal nitrogen removal with $\mathrm{C} / \mathrm{C}_{0}$ values of $0.265,0.228$ and 0.4 at $\mathrm{Fe}^{2+} / \mathrm{H}_{2} \mathrm{O}_{2}$ molar ratio of 1:2, 1:3 and 1:5 showing maximum removal at 1:3.

Previous studies reveal that due to the formation of hydro-peroxyl radical and auto-decomposition of hydrogen peroxide, the removal efficiency significantly decreases as

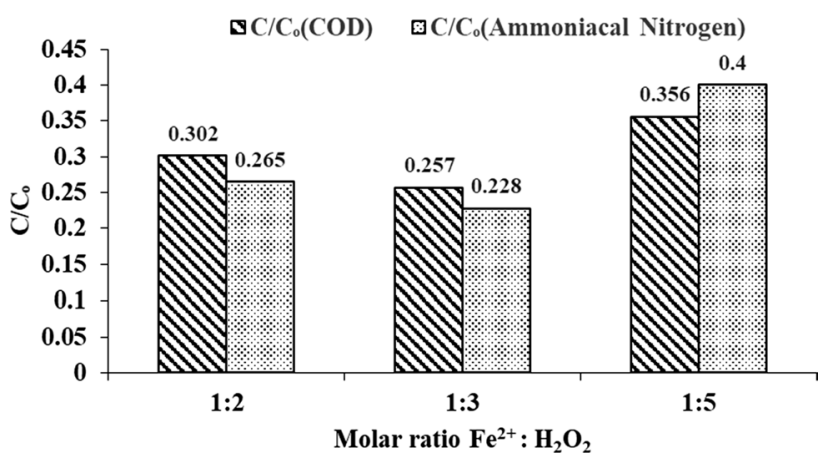

Fig. 3 Profile of fraction remaining set against molar ratio on degradation of $\mathrm{COD}$ and ammoniacal nitrogen by Fenton process at $\mathrm{pH}$ 3.0 and keeping $\mathrm{Fe}^{2+}$ molar concentration constant and varying $\mathrm{H}_{2} \mathrm{O}_{2}$ dosage 


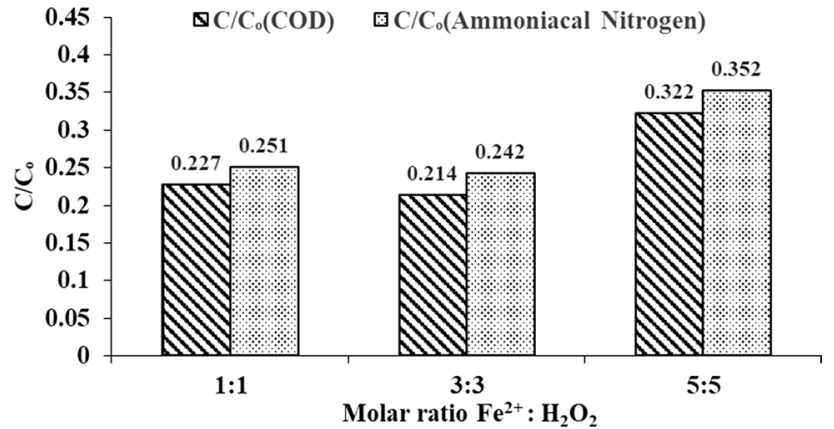

Fig. 4 Profile of fraction remaining set against molar ratio on degradation of COD and ammoniacal nitrogen by Fenton process at $\mathrm{pH} 3.0$ and increasing the concentration of doses by 3:3 and 5:5 (sample volume $1000 \mathrm{~mL}$ )

hydro-peroxyl radical has low oxidizing potential according to Eq. (6) (Wang et al. 2019; Nidheesh and Gandhimathi 2014).

$\mathrm{H}_{2} \mathrm{O}_{2}+\mathrm{OH}^{\cdot} \rightarrow \mathrm{H}_{2} \mathrm{O}+\mathrm{OH}_{2}$

Addition of excess $\mathrm{H}_{2} \mathrm{O}_{2}$ exceeding the optimum limit do not improve the degradation efficiency, which might be attributed to auto-decomposition of $\mathrm{H}_{2} \mathrm{O}_{2}$ to oxygen and water, and the recombination of $\mathrm{OH}^{-}$radicals (Mane et al. 2007; Xue et al. 2009). Moreover, higher concentrations of hydrogen peroxide act as free-radical scavenger itself, thereby decreasing the concentration of hydroxyl radicals and reducing compound elimination efficiency.

\section{Effect of $\mathrm{Fe}^{2+} / \mathrm{H}_{2} \mathrm{O}_{2}$ molar ratio}

As evident from Eq. (2), $\mathrm{H}_{2} \mathrm{O}_{2}$ and $\mathrm{Fe}^{2+}$ play an important role in the formation of $\mathrm{OH}^{-}$radical. The $\mathrm{OH}$ radical combines with the organic compounds (pollutants) and oxidizes them, thereby degrading (treating) them (as shown in Eq (7).

Organic comounds $+\mathrm{OH}^{*} \rightarrow$ Oxidation Products

Thus, it is imperative to determine the optimum molar ratio of $\mathrm{Fe}^{2+} / \mathrm{H}_{2} \mathrm{O}_{2}$ (Mohajeri et al. 2010) for the maximum treatment efficiency in terms of removal of COD and ammoniacal nitrogen. In the present study, molar ratio of $\mathrm{Fe}^{2+} / \mathrm{H}_{2} \mathrm{O}_{2}$ was varied as 1:1, 3:3 and 5:5 at $\mathrm{pH} 3$ with a reaction time of $60 \mathrm{~min}$. As seen in Fig. 4, maximum removal for both COD and ammoniacal nitrogen occurred at molar ratio 3:3 which was $78.6 \%$ and $75.2 \%$, respectively. At molar ratio 5:5, the treatment efficiency was $67.8 \%$ and $64.8 \%$ for COD and ammoniacal nitrogen, respectively. It is inferred that the reduction in the treatment efficiency could be because of the scavenging effect as shown in Eq. (6). These results showed that the reaction between excess $\mathrm{Fe}^{2+}$ and $\mathrm{HO}_{2}$ radical leads to redox reaction which enhances the removal efficiency of
COD and ammoniacal nitrogen (Gulkaya et al. 2006; Chu et al. 2012; Couto et al. 2016).

\section{Conclusions}

The current study was found to be an efficient method for degrading (treating) ammoniacal nitrogen and COD from industrial wastewater. The Fenton oxidation process can be better used to treat the industrial wastewater which contains high COD and high ammoniacal nitrogen with very high TDS. The Fenton process can mineralize the pollutants up to $75.8 \%$ and $78.6 \%$ for ammoniacal nitrogen and COD at optimum conditions of $\mathrm{pH} 3$ and the molar dosage of $\mathrm{Fe}^{2+}$ and $\mathrm{H}_{2} \mathrm{O}_{2}$ of 3:3 for 60 -min reaction time. The Fenton process can be carried out in a batch process with detention time of 60 min to degrade the COD and ammoniacal nitrogen.

Funding We thank Office of Research and Sponsored Programs-Pandit Deendayal Petroleum University for funding the project.

\section{Compliance with ethical standards}

Conflict of interest All authors declare no conflict of interest.

Open Access This article is licensed under a Creative Commons Attribution 4.0 International License, which permits use, sharing, adaptation, distribution and reproduction in any medium or format, as long as you give appropriate credit to the original author(s) and the source, provide a link to the Creative Commons licence, and indicate if changes were made. The images or other third party material in this article are included in the article's Creative Commons licence, unless indicated otherwise in a credit line to the material. If material is not included in the article's Creative Commons licence and your intended use is not permitted by statutory regulation or exceeds the permitted use, you will need to obtain permission directly from the copyright holder. To view a copy of this licence, visit http://creativecommons.org/licenses/by/4.0/.

\section{References}

Akpor OB, Muchie M (2011) Environmental and public health implications of wastewater quality. Afr J Biotechnol 10:2379-2387

Barbusiński K (2005) The modified Fenton process for decolorization of dye wastewater. Polish J Environ Stud 14(3):281-285

Barbusiński K, Majewski J (2003) Discoloration of azo dye acid red 18 by fenton reagent in the presence of iron powder. Polish J Environ Stud 12(2):151-155

Barros AL, Pizzolato TM, Carissimi E, Schneider IAH (2006) Decolorizing dye wastewater from the agate industry with Fenton oxidation process. Miner Eng 19:87-90

Bautista P, Mohedano AF, Gilarranz MA, Casas JA, Rodriguez JJ (2007) Application of Fenton oxidation to cosmetic wastewaters treatment. J Hazard Mater 143(1-2):128-134 
Bhatia D, Sharma NR, Kanwar R, Singh J (2018) Physicochemical assessment of industrial textile effluents of Punjab (India). Appl Water Sci 8:1-12

Bolong N, Ismail AF, Salim MR, Matsuura T (2009) A review of the effects of emerging contaminants in wastewater and options for their removal. Desalination 239:229-246

Buthiyappan A, Abdul Raman AA (2019) Energy intensified integrated advanced oxidation technology for the treatment of recalcitrant industrial wastewater. J Clean Prod 206:1025-1040

Camargo JA, Alonso Á (2006) Ecological and toxicological effects of inorganic nitrogen pollution in aquatic ecosystems: a global assessment. Environ Int 32:831-849

Chen Q, Liu H, Yang Z, Tan D (2017) Regeneration performance of spent granular activated carbon for tertiary treatment of dyeing wastewater by Fenton reagent and hydrogen peroxide. J Mater Cycles Waste Manag 19:256-264

Chu YY, Qian Y, Wang WJ, Deng XL (2012) A dual-cathode electroFenton oxidation coupled with anodic oxidation system used for 4-nitrophenol degradation. J Hazard Mater 199-200:179-185

Couto AB, Oishi SS, Ferreira NG (2016) Enhancement of nitrate electroreduction using BDD anode and metal modified carbon fiber cathode. J Ind Eng Chem 39:210-217

da Silva Brito GF, Oliveira R, Grisolia CK et al (2019) Evaluation of advanced oxidative processes in biodiesel wastewater treatment. J Photochem Photobiol A Chem 375:85-90

Deng Y, Zhao R (2015) Advanced oxidation processes (AOPs) in wastewater treatment. Curr Pollut Reports 1:167-176

Dükkanci M, Vinatoru M, Mason TJ (2014) The sonochemical decolourisation of textile azo dye Orange II: effects of Fenton type reagents and UV light. Ultrason Sonochem 21:846-853

Eren Z, Acar FN (2006) Effect of Fenton's reagent on the degradability of CI reactive yellow 15. Coloration Technol 122(5):259-263

Ge S, Peng Y, Qiu S, Zhu A, Ren N (2014) Complete nitrogen removal from municipal wastewater via partial nitrification by appropriately alternating anoxic/aerobic conditions in a continuous plugflow step feed process. Water Res 55:95-105

Gogate PR, Pandit AB (2004) A review of imperative technologies for wastewater treatment I: oxidation technologies at ambient conditions. Adv Environ Res 8:501-551

Gonzalez-Merchan C, Genty T, Bussière B, Potvin R, Paquin M, Benhamadi M, Neculita C (2016) Influence of contaminant to hydrogen peroxide to catalyzer molar ratio in the advanced oxidation of thiocyanates and ammonia nitrogen using Fenton-based processes. J Environ Chem Eng 4:4129-4136

Guedes AM, Madeira LM, Boaventura RA, Costa CA (2003) Fenton oxidation of cork cooking wastewater-overall kinetic analysis. Water Res 37(13):3061-3069

Gulkaya I, Surucu GA, Dilek FB (2006) Importance of $\mathrm{H}_{2} \mathrm{O}_{2} / \mathrm{Fe}^{2+}$ ratio in Fenton's treatment of a carpet dyeing wastewater. J Hazard Mater 136:763-769

Güneş E, Çifçi Dİ, Çelik SÖ (2018) Comparison of Fenton process and adsorption method for treatment of industrial container and drum cleaning industry wastewater. Environ Technol 39:824-830

Hasanoĝlu A, Romero J, Pérez B, Plaza A (2010) Ammonia removal from wastewater streams through membrane contactors: experimental and theoretical analysis of operation parameters and configuration. Chem Eng J 160:530-537

Huang H, Yang J, Li D (2014) Recovery and removal of ammonianitrogen and phosphate from swine wastewater by internal recycling of struvite chlorination product. Bioresour Technol 172:253-259

Jiang C, Pang S, Ouyang F, Ma J, Jiang J (2010) A new insight into Fenton and Fenton-like processes for water treatment. J Hazard Mater 174:813-817

Kang YW, Hwang KY (2000) Effects of reaction conditions on the oxidation efficiency in the Fenton process. Water Res 34:2786-2790
Karri RR, Sahu JN, Chimmiri V (2018) Critical review of abatement of ammonia from wastewater. J Mol Liq 261:21-31

Katheresan V, Kansedo J, Lau SY (2018) Efficiency of various recent wastewater dye removal methods: a review. J Environ Chem Eng 6:4676-4697

Kaur P, Sangal VK, Kushwaha JP (2019) Parametric study of electroFenton treatment for real textile wastewater, disposal study and its cost analysis. Int J Environ Sci Technol 16:801-810

Khatri J, Nidheesh PV, Anantha Singh TS, Suresh Kumar M (2018) Advanced oxidation processes based on zero-valent aluminium for treating textile wastewater. Chem Eng J 348:67-73

Lotito AM, Fratino U, Bergna G, Di Iaconi C (2012) Integrated biological and ozone treatment of printing textile wastewater. Chem Eng J 195-196:261-269

Mane VS, Mall ID, Srivastava VC (2007) Use of bagasse fly ash as an adsorbent for the removal of brilliant green dye from aqueous solution. Dye Pigment 73:269-278

Markandeya Dhiman N, Shukla SP, Mohan D (2018) Comprehensive remediation study of disperse dyes in wastewater using cenospheres nanosyntactic foam. J Clean Prod 182:206-216

Meng X, Khoso SA, Wu J, Tian M, Kang J, Liu H, Jhang Q, Sun W, Hu $Y$ (2019) Efficient COD reduction from sulfide minerals processing wastewater using Fenton process. Miner Eng 132:110-112

Mohajeri S, Aziz HA, Isa MH, Zahed MA, Adlan MN (2010) Statistical optimization of process parameters for landfill leachate treatment using electro-Fenton technique. J Hazard Mater 176:749-758

Moussavi M, Matavos-Aramyan S (2016) Chelate-modified fenton treatment of sulfidic spent caustic. Korean J Chem Eng 33(8):2384-2391

Nancharaiah YV, Venkata Mohan S, Lens PNL (2016) Recent advances in nutrient removal and recovery in biological and bioelectrochemical systems. Bioresour Technol 215:173-185

Nidheesh PV (2015) Heterogeneous Fenton catalysts for the abatement of organic pollutants from aqueous solution: a review. RSC Adv 5:40552-40577

Nidheesh PV, Gandhimathi R (2012) Trends in electro-Fenton process for water and wastewater treatment: an overview. Desalination 299:1-15

Nidheesh PV, Gandhimathi R (2014) Effect of solution pH on the performance of three electrolytic advanced oxidation processes for the treatment of textile wastewater and sludge characteristics. RSC Adv 4:27946-27954

Nidheesh PV, Zhou M, Oturan MA (2018) An overview on the removal of synthetic dyes from water by electrochemical advanced oxidation processes. Chemosphere 197:210-227

Oturan MA, Aaron JJ (2014) Advanced oxidation processes in water/ wastewater treatment: principles and applications. A review. Crit Rev Environ Sci Technol 44:2577-2641

Papić S, Vujević D, Koprivanac N, Šinko D (2009) Decolourization and mineralization of commercial reactive dyes by using homogeneous and heterogeneous Fenton and UV/Fenton processes. J Hazard Mater 164:1137-1145

Paździor K, Bilińska L, Ledakowicz S (2018) A review of the existing and emerging technologies in the combination of AOPs and biological processes in industrial textile wastewater treatment. Chem Eng J 376:120597

Quan X, Ye C, Xiong Y, Xiang J, Yang F (2010) Simultaneous removal of ammonia, $\mathrm{P}$ and COD from anaerobically digested piggery wastewater using an integrated process of chemical precipitation and air stripping. J Hazard Mater 178:326-332

Rathi AKA (2003) Promotion of cleaner production for industrial pollution abatement in Gujarat (India). J Clean Prod 11:583-590

Sabumon PC (2007) Anaerobic ammonia removal in presence of organic matter: a novel route. J Hazard Mater 149:49-59

Shao B, Guan Y, Tian Z, Guan X, Wu D (2016) Advantages of aeration in arsenic removal and arsenite oxidation by structural Fe(II) 
hydroxides in aqueous solution. Colloids Surf A: Physicochem Eng Asp 506:703-710

Singa PK, Isa MH, Ho YC, Lim JW (2018) Treatment of hazardous waste landfill leachate using Fenton oxidation process. In: E3S Web of conferences, vol 34, pp 4-9

Tony MA, Parker HL, Clark JH (2016) Treatment of laundrette wastewater using Starbon and Fenton's reagent. J Environ Sci Health A Toxic/Hazard Subst Environ Eng 51(11):974-979

Wang Y, Liu S, Xu Z et al (2006) Ammonia removal from leachate solution using natural Chinese clinoptilolite. J Hazard Mater 136:735-740

Wang N, Zheng T, Zhang G, Wang P (2016) A review on Fenton-like processes for organic wastewater treatment. J Environ Chem Eng 4:762-787

Wang Z, Li J, Tan W et al (2019) Removal of COD from landfill leachate by advanced Fenton process combined with electrolysis. Sep Purif Technol 208:3-11

Xue X, Hanna K, Deng N (2009) Fenton-like oxidation of Rhodamine $\mathrm{B}$ in the presence of two types of iron (II, III) oxide. J Hazard Mater 166:407-414
Yuan MH, Chen YH, Tsai JY, Chang CY (2016) Ammonia removal from ammonia-rich wastewater by air stripping using a rotating packed bed. Process Saf Environ Prot 102:777-785

Zhang Y, Zhou M (2019) A critical review of the application of chelating agents to enable Fenton and Fenton-like reactions at high $\mathrm{pH}$ values. J Hazard Mater 362:436-450

Zhang MF, Qin YH, Ma JY, Yang L, Wu ZK, Wang TL, Wang WG, Wang CW (2016) Depolymerization of microcrystalline cellulose by the combination of ultrasound and Fenton reagent. Ultrason Sonochem 31:404-408

Publisher's Note Springer Nature remains neutral with regard to jurisdictional claims in published maps and institutional affiliations. 